\title{
The smartphone in self-regulated learning and student success: clarifying relationships and testing an intervention
}

\author{
Kendall Hartley ${ }^{{ }^{*}}$ (D), Lisa D. Bendixen ${ }^{2} \mathbb{D}$, Dan Gianoutsos ${ }^{3}$ (D) and Emily Shreve ${ }^{3}$
}

\author{
*Correspondence: kendall.hartley@ \\ unlv.edu \\ ${ }^{1}$ Department of Teaching and \\ Learning, University of Nevada, Las \\ Vegas, 4505 S. Maryland Parkway, \\ Box \#453005, Las Vegas, NV \\ 89154-3005, USA \\ Full list of author information is \\ available at the end of the article
}

\begin{abstract}
This two-part observational and intervention study addressed the role of the smartphone in self-regulated learning (SRL) and student success as measured by achievement. Smartphone usage among students has been identified as contributing to lower academic achievement in a variety of settings. What is unclear is how smartphone usage contributes to lower outcomes. This study surveyed participants' self-regulated learning skills and smartphone usage at the beginning and end of the term for first semester undergraduates. A regression analysis demonstrated that when controlling for prior achievement, general SRL measures had a positive impact on first semester achievement. Smartphone related SRL did not have a direct impact on achievement. The second part of the study evaluated the efficacy of a brief intervention to ameliorate factors contributing to lower achievement. Students were presented with either SRL strategies, awareness and attention strategies or career planning guidance (control). A regression analysis of the brief intervention resulted in modest gains in SRL but did not influence achievement.
\end{abstract}

Keywords: Self-regulated learning, Metacognition, Smartphones and learning, Mobile learning

Smartphone usage among students has the potential to support and hinder academic success. Previous research has indicated that higher cell-phone use is associated with lower academic performance (Chen \& Yan, 2016; Lepp, Barkley, \& Karpinski, 2015; Rosen, Carrier, \& Cheever, 2013). Others suggest that smartphones can serve as a learning aid (Anshari, Almunawar, Shahrill, Wicaksono, \& Huda, 2017; Ariel \& Elishar-Malka, 2019; Dalvi-Esfahani, Wai Leong, Ibrahim, \& Nilashi, 2020; Nguyen, Muilu, Dirin, \& Alamäki, 2018). How the smartphone is used (or not used) by the learner will go a long way in determining the impact on learning. Prior research has indicated that certain types of smartphone uses, such as multitasking while studying, are related to learner skills such as cognitive resource management (Hartley, Bendixen, Shreve, Gianoutsos, \& Olafson, 2020). Interventions that shift student behavior while studying towards more effective strategies will lead to better academic outcomes.

(c) The Author(s). 2020 Open Access This article is licensed under a Creative Commons Attribution 4.0 International License, which permits use, sharing, adaptation, distribution and reproduction in any medium or format, as long as you give appropriate credit to the original author(s) and the source, provide a link to the Creative Commons licence, and indicate if changes were made. The images or other third party material in this article are included in the article's Creative Commons licence, unless indicated otherwise in a credit line to the material. If material is not included in the article's Creative Commons licence and your intended use is not permitted by statutory regulation or exceeds the permitted use, you will need to obtain permission directly from the copyright holder. To view a copy of this licence, visit http://creativecommons.org/licenses/by/4.0/. 
The purpose of this research is to a) clarify the relationship between smartphone usage among students as it relates to learning and academic achievement and b) test the efficacy of a brief intervention designed to increase smartphone uses and studying behaviors that are supportive of learning.

\section{Smartphone use and cognitive resources}

The smartphone can introduce substantial burdens on a learner's cognitive resources. As it is currently conceived, the smartphone is distracting and particularly detrimental to learners attempting to study (Aharony \& Zion, 2019; May \& Elder, 2018). The core functionality and use of the smartphone is based largely on the notification. This can be a beep, vibration, or visual cue. The notification is the cue for the user to make a decision. Regardless of the decision, the distraction has now occurred. The focused attention of the learner is disrupted and progress on the initial task will suffer (Chen \& Yan, 2016; Terry, Mishra, \& Roseth, 2016).

While notifications and distractions represent one challenge to the learner, the propensity to use the smartphone to support multitasking is another significant obstacle (Kirschner \& De Bruyckere, 2017). The multimedia capacity of the smartphone encourages nearly continual consumption of multiple media streams. A recent study reported the mean number of apps used by college students while doing homework was 4.9 (Patterson, 2017). The same study reported that higher levels of multitasking while studying were associated with lower levels of exam performance. The consumption of multiple media is expanding as the use of multiple devices increases. The learner is often surrounded by an array of technological devices vying for attention (Chen \& Koufaris, 2020).

In a review of media multitasking and academic performance research May and Elder (2018) observed:

Laptops and mobile phones are particularly distracting while studying or doing course-work outside of class, as students can easily access alternate media sources such as email, Facebook, or Instant Messaging (IM) on them. Much of the research to date primarily assessed the impact of media multitasking on in-class activities, such as test performance. Few studies have examined the role of media multitasking on assignments outside of class, such as homework or studying. (p. 8).

This research targeted the smartphone related habits of learners while studying and the consequent impact on achievement.

\section{Self-regulated learning}

Student awareness of the cognitive challenges presented by the smartphone is unclear. Is the deleterious use of the smartphone a result of unawareness or apathy? In other words, do learners understand the negative impact on the learning and choose to continue the behavior regardless? Or, do they believe smartphone use while learning does not adversely impact productivity (i.e., learning)?

Self-regulated learning (SRL) theory is used as a framework to address these questions. Broadly conceived, SRL incorporates learner motivation, metacognitive awareness, cognitive skills and beliefs about learning (Muis, 2007; Schraw \& Dennison, 1994; Usher \& Schunk, 2018). A description of SRL from Usher and Schunk (2018) provides relevant context: 
The process of systematically organizing one's thoughts, feelings, and actions to attain one's goals is now commonly referred to as self-regulation. In this information-rich, fast-paced world, individuals are presented with many possible paths of thought and behavior, which can sometimes feel overwhelming. (p. 32).

The well self-regulated learner recognizes limits on cognitive capacity and the necessity to be strategic in the deployment of these resources (Schraw \& Dennison, 1994; Zimmerman \& Schunk, 2011). This knowledge generally is revealed with increased effort, time management, and focused attention (Mrazek et al., 2018; Pintrich \& De Groot, 1990; Zimmerman \& Kitsantas, 2014). This becomes key in an environment that seems to encourage cyberloafing (Durak, 2020). In an analysis of variables related to classroom multitasking, self-regulation has been identified as a key influence on multitasking (Zhang, 2015). Similarly, students who report low multitasking behaviors (or high focus) while studying exhibit higher levels of self-regulated learning behaviors such as time management and focused effort Hartley, Bendixen, Shreve, et al., 2020).

This research pays particular attention to the resource management component of SRL as it has demonstrated clear impacts on academic achievement (Pintrich \& De Groot, 1990; Pintrich, Smith, Garcia, \& Mckeachie, 1991) and is strongly related to smartphone usage while studying (Hartley, Bendixen, Shreve, et al., 2020). Resource management includes activities such as exerting increased effort towards difficult content and establishing a study environment conducive to focused attention.

\section{Changing behavior}

Ultimately, the importance of clarifying the relationships between smartphone usage, SRL, and learning is in the service of identifying strategies to improve learning outcomes. Addressing self-regulatory skills is a natural conduit for improving academic performance (Mrazek et al., 2018). Given the relationships between smartphone usage, SRL, and achievement, modifications to how the smartphone is used are also appropriate (Dalvi-Esfahani et al., 2020). In addition, given the ubiquity of the smartphone, it is prudent to utilize it in any SRL intervention (e.g, as a support for cue-based interventions; van Merriënboer \& de Bruin, 2019).

Like any instructional goal, substantial changes in behavior are best supported by activities that are well-planned, long-term, time-intensive, and highly engaging. Unfortunately, the opportunities to implement these activities with the current population (new college students) are limited. The existing curriculum is already viewed as impacted. Thus, adding additional components on top of the standard curriculum risks information and activity fatigue for both instructors and students alike. The goal is to identify an intervention that does not detract from the main goals of a course, is seamlessly integrated into the student experience, and requires minimal instructor support.

Brief interventions have garnered substantial interest in the area of implicit theories of intelligence. These interventions involve little more than introductory instructions that frame the activity in a different light or modifications to the type of feedback provided (Walton, 2014). Researchers have found that inducing a growth mindset (or incremental theory of intelligence) can be achieved with young children through simple adjustments to task feedback by complementing learners on hard work rather than 
praising intelligence (Dweck, 2008). Others have had mixed results with brief task instructions and college students (Bråten, Lien, \& Nietfeld, 2017).

More substantive interventions have provided more reliable outcomes with young adults. Researchers studying college students have had success with a 2-h online training that required limited instructor intervention (Bernacki, Vosicka, \& Utz, 2019). There is evidence that a semester-long intervention that incorporates instructor modeling can improve beliefs about learning and the use of SRL strategies such as elaboration (Muis \& Duffy, 2013). While this intervention was introduced over a larger time frame, the additional time required was minimal in that it replaced one interaction and questioning approach (traditional/control) with another (epistemic beliefs/intervention).

Morisano, Hirsh, Peterson, Pihl, and Shore (2010) investigated the impact of an online, personal goal-setting intervention among self-nominated, academically struggling college students $(n=85)$ at a four-year research institution. Participants were randomly assigned to a goal group or control group; each group completed a 2.5 -h guided online program on their own time, outside of a course, with no instructor engagement. The goal group saw two major benefits in the semester post-intervention: GPA improvement and a greater likelihood of maintaining at least a nine-credit course load.

In a recent large-scale study examining lower-achieving high school students, Yeager et al. (2019) utilized a scalable, online growth mindset intervention consisting of two brief sessions that averaged 25 min each session with most institutions distributing the sessions around 3 weeks apart. The intervention required no additional teaching from instructors. The results suggested notable gains in enrolling in advanced-math courses, and for the schools where peer norming aligned with the intervention content, grades were improved.

In summary, research indicates that well-conceived short-term interventions can have a positive influence on academic achievement and related behaviors. This study aimed to extend these findings to smartphone usage as it relates to learning.

\section{Present research}

The current study aimed to address two questions. What is the relationship between limited smartphone usage while studying (LSU), SRL (as measured by resource management), and academic achievement? Can a brief intervention positively impact smartphone usage and self-regulation over the course of a semester?

\section{Relationship between SRL, limited smartphone usage while studying, and achievement}

The model described in Fig. 1 represents the proposed relationship between SRL as measured by resource management, limited smartphone usage (LSU) while studying and achievement while controlling for prior achievement. Prior research has demonstrated a positive relationship between resource management and LSU while studying (Hartley, Bendixen, Shreve, et al., 2020). See arrow A in Fig. 1. Similarly, prior research has demonstrated a positive relationship between resource management and achievement (Pintrich \& De Groot, 1990; Robbins et al., 2004) or arrow C. While overall smartphone usage has a deleterious effect on achievement (Lepp et al., 2015) the relationship between LSU while studying and achievement (arrow B) has not been directly 


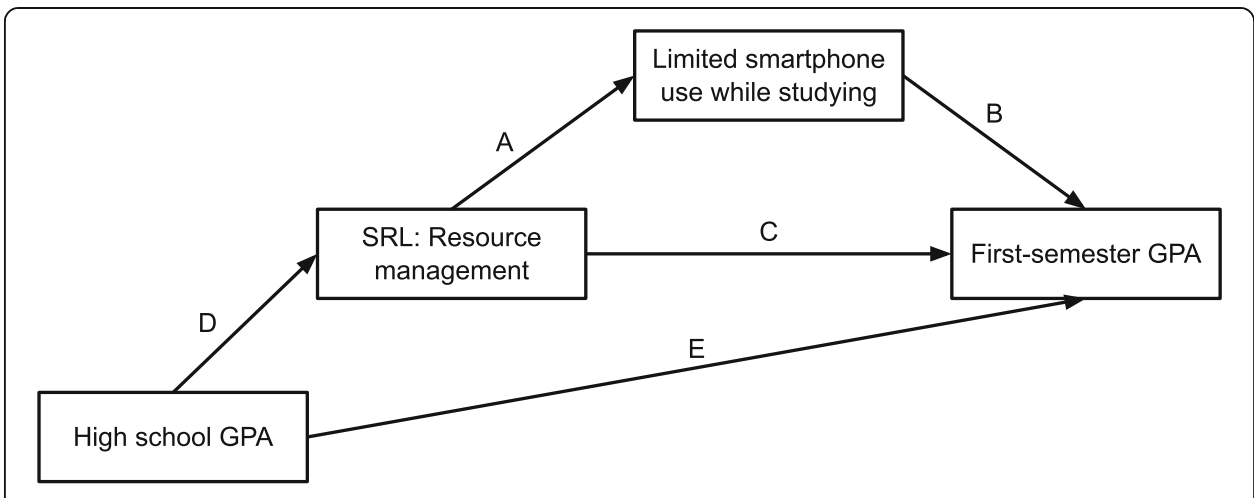

Fig. 1 Proposed Model of Resource Management, Limited Smartphone Usage and 1st Semester GPA

addressed. In addition, the indirect impact of resource management on achievement through LSU while studying has not been investigated.

The proposed model (Fig. 1) presents resource management as a trait that temporally precedes LSU while studying. In other words, it suggests that the learner's resource management traits influence smartphone use. Subsequently, smartphone usage will influence the first-semester GPA.

\section{Can a brief intervention positively impact SRL and limited smartphone usage while learning?}

The exercises were inspired by interventions described by (Morisano et al., 2010) and Yeager et al. (2019). However, the intervention utilized here was shorter in duration and intentionally designed to have minimal impact on instructor and student resources. Participants were guided through one of three brief exercises on (1) career planning (CP, control), (2) academic planning (AP), or (3) attention and awareness (AA).

Hypotheses:

1. Limited smartphone usage while studying, SRL, and Achievement

a. When controlling for prior achievement, SRL will have a positive influence on the first semester GPA.

b. When controlling for prior achievement, SRL mediated by limited smartphone usage will have a positive influence on the first semester GPA.

c. When controlling for prior achievement, limited smartphone usage will have a positive influence on the first semester GPA.

2. Instructional Intervention

a. Intervention participants will earn higher grades than control participants.

b. Intervention participants will report less smartphone use while studying smartphone when compared to control participants.

c. Intervention participants will report increased SRL when compared to control participants.

\section{Method}

The study design reflects the dual nature of the research questions. Research question one addresses the suitability of the model described in the previous section (Fig. 1). 
The design for this question was strictly observational. Measures of the model independent variables (prior achievement, SRL, and LSU) were collected early in the term and the dependent variable (GPA) was collected once at the conclusion of the term. Research question two was addressed with an experimental design. An independent variable was added by randomly assigning participants to one of three groups (control, academic planning, and attention/awareness). The dependent variables of interest for question two were overall GPA, as well as end-of-semester LSU and SRL.

\section{Participants}

This study was conducted as a component of a larger effort to assess first-year college student success. The study was reviewed and approved by the university Institutional Review Board. The participant pool for this study included all students enrolled in a first-year seminar in the Spring and Fall of 2019 at a large research university in the southwest United States. These students completed an extensive battery of measures related to student success during the third (pre) and 12th (post) week of the semester. The data set for this study utilized the responses from all students who a) reviewed the approved informed consent form and agreed to participate in the study, b) were 18 years old or older, c) completed each section of the Fall 2019 pre and post survey, d) had not yet completed any coursework at the university (i.e., first semester), and e) had a high school GPA available in the student information system. The resulting dataset consisted of 289 participants (147 male, 142 female; age range $18-25$, mean $=18.2$ ).

\section{Measures}

\section{Limited smartphone usage (LSU) while studying}

The smartphone and learning inventory (SALI) was used to measure the use of the phone as it relates to learning. SALI consists of three factors, mindful usage, phone knowledge, and limited smartphone usage (LSU) while studying (previously focus on studying) (Hartley, Bendixen, Olafson, Gianoutsos, \& Shreve, 2020; Hartley, Bendixen, Shreve, et al., 2020). The LSU factor was used for this study due to the strong relationship with SRL and cognitive resource management. This factor has demonstrated good reliability with a Cronbach's alpha of .80 .

\section{Resource management}

SRL in general and resource management in particular was measured with the Motivated Strategies for Learning Questionnaire (MSLQ; Pintrich et al., 1991). While the original conception of resource management in the MSLQ consisted of four subscales, subsequent analyses have called into question two of the subscales (Hilpert et al., 2013). This study will utilize the remaining resource management sub-scales 1) time and study environment (e.g., "I make good use of my study time") and 2) effort regulation (e.g., "I work hard to do well in class, even if I don't like what we are doing"). Eight items from these subscales were chosen based upon the strength of the relationship to academic performance (Pintrich et al., 1991). 


\section{Achievement}

Student high school GPAs were used as indicators of prior achievement. College academic performance is indicated by the first semester GPA for all courses.

\section{Procedures}

During the third (pre) and 12th (post) week of the semester students were asked to complete in-class several measures including those described above via an online Qualtrics survey. Within the initial survey, students were randomly assigned to one of three groups. The three groups were career planning (control), academic planning (AP), and attention/awareness (AA). Each group read a first-person account from a fictitious graduating student regarding challenges they faced when they first started college. The student then described how they set goals to overcome the challenge. The participant was then prompted to set their own goals to meet the challenge. Table 1 provides a summary of each challenge and the subsequent goal setting activities.

Upon completion, the participants received a copy of the responses to the goal setting activity via email. After one week, the students received another email reminding them of the goals for the week. This reminder included a link to a one-week follow-up survey to determine how well they met their goals. A similar reminder and survey were sent after three additional weeks had passed. During the 12th week of the course, students completed the post survey.

\section{Results}

RQ1 relationship between SRL, limited smartphone usage while studying, and achievement

The exploration of the relationship between resource management, LSU while studying, and achievement began with a review of the relevant correlations (see Table 2 and Fig. 2). As expected, resource management as measured by the MSLQ resource management subscale was positively correlated with prior achievement, LSU while studying, and first semester GPA. The correlation between LSU while studying and first semester GPA was not statistically significant.

Given that the correlation between LSU while studying and first semester GPA was not statistically significant, it was unnecessary to further investigate the direct and indirect effects of the resource management and LSU while studying. To clarify the unique contribution of SRL: Resource management a sequential regression analysis was

Table 1 Intervention group assignments

\begin{tabular}{|c|c|c|c|}
\hline $\begin{array}{l}\text { Group } \\
\text { assigned }\end{array}$ & Intervention & $\begin{array}{l}\text { Challenge faced by } \\
\text { student }\end{array}$ & Goal setting \\
\hline $\begin{array}{l}\text { Career } \\
\text { Planning } \\
(\mathrm{CP})\end{array}$ & Control & $\begin{array}{l}\text { Unsure of future } \\
\text { career }\end{array}$ & Investigate potential careers \\
\hline $\begin{array}{l}\text { Academic } \\
\text { Planning } \\
\text { (AP) }\end{array}$ & $\begin{array}{l}\text { Encourage } \\
\text { planning }\end{array}$ & $\begin{array}{l}\text { How to succeed in } \\
\text { college }\end{array}$ & $\begin{array}{l}\text { Increase planning, organization, and effort towards } \\
\text { academics with self-identified goals }\end{array}$ \\
\hline $\begin{array}{l}\text { Attention / } \\
\text { Awareness } \\
\text { (AA) }\end{array}$ & $\begin{array}{l}\text { Increase attention } \\
\text { and avoid } \\
\text { distractions }\end{array}$ & $\begin{array}{l}\text { Difficulty remaining } \\
\text { focused on school } \\
\text { work }\end{array}$ & $\begin{array}{l}\text { Utilize strategies to increase focus while studying } \\
\text { (e.g., set phone to silent; use timers to monitor } \\
\text { focused study-time) }\end{array}$ \\
\hline
\end{tabular}


Table 2 Means, standard deviations, correlations, and Cronbach's alpha (parentheses in matrix diagonal) for all variables

\begin{tabular}{llllll}
\hline Variable & Mean & SD & Resource management & LSU while studying & High school GPA \\
\hline SRL: Resource management & 30.7 & 4.33 & $(.75)$ & & \\
LSU while studying & 20.2 & 5.41 & $.302^{* * *}$ & $(.74)$ & \\
High School GPA & 3.69 & .49 & $.192^{* *}$ & .027 & $.424^{* * *}$ \\
First Semester GPA & 3.13 & .81 & $.266^{* * *}$ & .046 & \\
${ }^{*} p<.05 .{ }^{* *} p<.01 .{ }^{* * *} p<$. 001. (1-tailed) & & & &
\end{tabular}

completed in two blocks (Table 3). First semester GPA was first regressed on prior achievement (high school GPA). Next, resource management and LSU while studying was added. The addition of the two variables produced a statistically significant change in variance explained $\left(\Delta R^{2}=.025, p<.05\right)$. Resource management was a significant positive predictor of first semester GPA $(\beta=.17, p<.01)$. LSU while studying was not a significant predictor of first semester GPA $(\beta=-.04, p=.53)$.

\section{Research question 2}

A series of regression analyses were completed to investigate any differences in first semester GPA, resource management and LSU while studying that might be attributed to the intervention. The three groups were identified through two variables, academic planning (AP; $1=$ yes, $0=$ no), and attention and awareness (AA; $1=$ yes, $0=$ no). Those in the career planning $(\mathrm{CP})$ or control group were coded as 0 for both variables.

Following the previous analyses, first semester grades was first regressed on high school GPA, and resource management. Model two added the intervention group variables (Table 4). The addition of the grouping did not produce a statistically significant change in variance explained $\left(\Delta R^{2}=.001\right)$ indicating that group membership did not have an impact on first semester grades.

To determine if the interventions had an impact on LSU while studying, participants pre and post scores were analyzed (Table 5). End-of-semester LSU while studying was regressed on the pre-scores for LSU while studying in block one. The second block added the intervention groupings. The addition of the grouping did not produce a statistically significant change in the variance explained $\left(\Delta R^{2}=.001\right.$; non-significant).

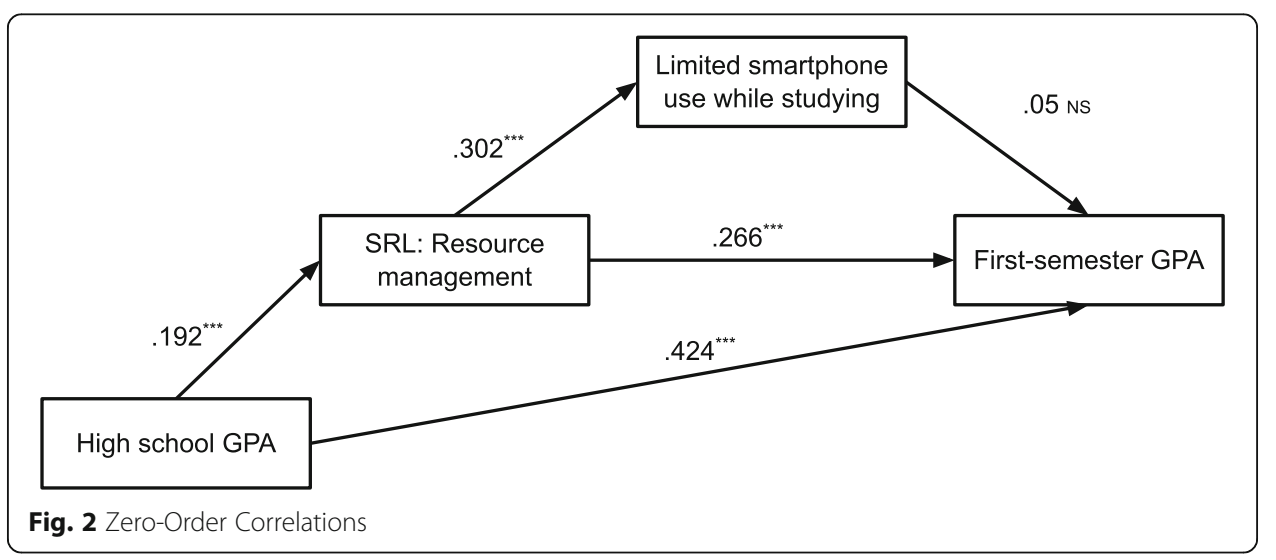


Table 3 First semester GPA, resource management and LSU regression analysis

\begin{tabular}{|c|c|c|c|c|c|c|}
\hline \multirow[t]{2}{*}{ Predictor } & \multicolumn{3}{|c|}{ Model 1} & \multicolumn{3}{|c|}{ Model 2} \\
\hline & $B$ & B & SE B & $B$ & B & SE B \\
\hline Constant & .49 & & .34 & -.19 & & .42 \\
\hline High School GPA & $.72^{* * *}$ & .43 & .09 & $.67^{* * *}$ & .40 & .09 \\
\hline Resource management & & & & $.03^{* *}$ & .17 & .01 \\
\hline LSU while studying & & & & -.01 & -.04 & .01 \\
\hline$R^{2}$ & & .187 & & & .212 & \\
\hline$\Delta R^{2}$ & & & & & $.025^{*}$ & \\
\hline
\end{tabular}

To determine if the interventions had an impact on resource management, participants pre and post scores were analyzed (Table 6). End-of-semester resource management was regressed on the pre-test resource management in block one. The second block added the intervention groupings. The addition of the grouping did not produce a statistically significant change in the variance explained $\left(\Delta R^{2}=.010\right.$; non-significant). Although the overall model was not significant, the coefficient for the attention and awareness intervention group was statistically significant $(ß=.239, p<.05)$.

\section{Discussion}

Relationship between SRL resource management, LSU while studying, and GPA

The first research question and sub-questions sought to bring clarity to the relationship between cognitive resource management, a particular type of smartphone usage among students, and academic achievement.

\section{Resource management}

The results supported the expected positive relationship between this component of self-regulated learning and limited smartphone usage among students while studying. This is consistent with earlier findings regarding the relationship between SRL and various uses of the smartphone while studying. In particular, the findings here are consistent with recent research that revealed a negative relationship between distracting smartphone usage (e.g., watching videos while studying) and cognitive resource management (Hartley, Bendixen, Shreve, et al., 2020). Cognitive

Table 4 Sequential regression of first semester GPA

\begin{tabular}{|c|c|c|c|c|c|c|}
\hline \multirow[b]{2}{*}{ Predictor } & \multicolumn{3}{|l|}{ Model 1} & \multicolumn{3}{|c|}{ Model 2} \\
\hline & $B$ & B & $\overline{\text { SE B }}$ & $\bar{B}$ & B & $\overline{S E B}$ \\
\hline Constant & -.238 & & .41 & -.244 & & .42 \\
\hline High School GPA & $.663^{* * *}$ & .403 & .09 & $.664^{* * *}$ & .404 & .09 \\
\hline Resource Management Post-test & $.030^{* *}$ & .162 & .01 & $.029^{* *}$ & .157 & .01 \\
\hline Attention and Awareness Group & & & & .027 & .034 & .11 \\
\hline Academic Planning Group & & & & .064 & .079 & .10 \\
\hline$R^{2}$ & & .214 & & & .215 & \\
\hline$\Delta R^{2}$ & & & & & .001 & \\
\hline
\end{tabular}


Table 5 Limited smartphone usage while studying post intervention

\begin{tabular}{|c|c|c|c|c|c|c|}
\hline \multirow[b]{2}{*}{ Predictor } & \multicolumn{3}{|l|}{ Model 1} & \multicolumn{3}{|l|}{ Model 2} \\
\hline & $B$ & B & $\overline{S E B}$ & $B$ & $\beta$ & SE B \\
\hline Constant & 6.82 & & .90 & & & \\
\hline Smartphone and Learning / Focus Pretest & $.666^{* * *}$ & .672 & .04 & $.669^{* * *}$ & .620 & .05 \\
\hline Attention and Awareness Group & & & & .280 & .052 & .57 \\
\hline Academic Planning Group & & & & -.136 & -.025 & .56 \\
\hline$R^{2}$ & & .451 & & & .452 & \\
\hline$\Delta R^{2}$ & & & & & .001 & \\
\hline
\end{tabular}

resource management exhibited a strong positive relationship to prior achievement and first semester grades which is also consistent with prior research (Pintrich \& De Groot, 1990; Robbins et al., 2004).

The continued strong influence on academic outcomes exhibited by this particular component of SRL is notable and worthy of deeper investigation. The population of interest in this study, students beginning the transition from secondary to postsecondary education, are entering a key stage of development. Students attitudes and understanding of their own cognitive resources and how to best manage those resources are critical but not complicated. Behaviors such as working hard and establishing good study habits may seem obvious to educators. However, adolescents transitioning to a more independent environment may not fully recognize the importance of such behaviors.

\section{Limited smartphone usage while studying}

The hypothesis that focused smartphone usage while studying would demonstrate a positive impact on first semester grades was not supported in this study. This is interesting for a number of reasons. The findings indicate that resource management does not, in spite of strong direct effects on smartphone usage (as measured here), exercise any indirect effects on grades via the use of the smartphone. When considering this in light of other findings that implicate smartphone usage with negative outcomes (Lepp et al., 2015) it remains to be determined precisely what type of use is to blame.

Table 6 Resource management post intervention

\begin{tabular}{|c|c|c|c|c|c|c|}
\hline \multirow[b]{2}{*}{ Predictor } & \multicolumn{3}{|l|}{ Model 1} & \multicolumn{3}{|l|}{ Model 2} \\
\hline & $\mathrm{B}$ & B & SE B & $\mathrm{B}$ & B & SE B \\
\hline Constant & 9.44 & & 1.49 & 8.89 & & 1.52 \\
\hline Resource Management Pretest & $.663^{* * *}$ & .621 & .05 & $.662^{* * *}$ & .620 & .05 \\
\hline Attention and Awareness Group & & & & $1.088^{*}$ & .239 & .51 \\
\hline Academic Planning Group & & & & .737 & .162 & .50 \\
\hline$R^{2}$ & & .386 & & & .395 & \\
\hline$\Delta R^{2}$ & & & & & .010 & \\
\hline
\end{tabular}




\section{Intervention}

The second questions and related sub-questions were designed to test the efficacy of a brief instructional intervention. It was designed to encourage positive growth in the participant's smartphone usage and general academic performance. The intervention was very brief and was heavily dependent upon the learner to engage meaningfully with the activity. In addition, there were indications that the task was given a low priority by students. For example, less than $10 \%$ of the students completed the week one and week three follow-up surveys. This low participation rate is consistent with virtually all attempts to engage this population via email, which is generally not the preferred mode of interaction. Regardless, it is possible that the "stickiness" of this intervention was limited. The incorporation of the intervention within an existing survey may have also adversely impacted the participants investment in the activity. This population is not immune to the survey fatigue afflicting everyone in higher education. In spite of these factors, there were modest indications that the intervention had an impact. In particular, the impact on the post-test cognitive resource management scores was encouraging.

As noted above, this population is positioned at a critical juncture in their academic progression. It is encouraging that there are indications of malleability of SRL skills such as resource management. While this intervention was intentionally spartan a more resource intensive approach may be justified given the strong impact of resource management on student success.

Subsequent research can augment this intervention with attributes that have demonstrated success in similar efforts (e.g., Bernacki et al., 2019; Nguyen et al., 2018). Increasing engagement in the intervention will be key and there are indications that some level of 'gamification' can support technology based interventions (Schindler, Burkholder, Morad, \& Marsh, 2017). Of particular interest is work that emphasizes interventions with adolescents that are more consistent with their own realities (Yeager, Dahl, \& Dweck, 2018):

Traditional interventions often focus on providing knowledge or self-regulation skills with the intent of suppressing short-term desires for the sake of long-term goals. In doing so, these interventions may ignore or fight against the powerful reasons why adolescents are engaging in the "problem" behavior in the first place (for a related argument, see Ellis et al., 2012). (p. 105).

This study intentionally targeted a specific aspect of self-regulated learning, resource management, for a variety of reasons described earlier. The deficits of this approach include the limited consideration of the motivational aspects of self-regulated learning. As the Yeager et al., quote above makes clear, the backdrop for the studying behaviors exhibited by adolescents is complicated. Issues of autonomy, competence, and relatedness (i.e., self-determination theory) are natural directions to investigate to determine how to best support learners (Deci \& Ryan, 2012; Jeno, Adachi, Grytnes, Vandvik, \& Deci, 2019). This is particularly relevant in an era of hyper-connectivity where the erosion of time and space boundaries suggest that adolescents should always be available.

\section{Conclusions}

The relationship between SRL, smartphone usage among students, and academic achievement is being progressively mapped out through this and other research. This is an important avenue for investigation given the both the prevalence of the smartphone 
and the clear import of SRL for learners. The reasons for a negative relationship between student smartphone usage and academic achievement are not yet clear. While this study provided some clues to this negative relationship, it was far from confirmatory. Investigations of other parameters of student smartphone usage such as what has been termed 'mindful' may provide a clearer model of association (Brown \& Ryan, 2003; Gorman \& Green, 2016).

Intervention research to support learner success in a manner that is impactful and scalable is also progressing. Numerous large scale programs of research are providing roadmaps for interventions that can be introduced without major investments or upheaval of extant curricula (Morisano et al., 2010; Walton, 2014; Yeager et al., 2018). Investigations such as this one provide additional guidance around issues such as implementation fidelity and learner engagement that can contribute to continued progress.

\section{Abbreviations}

SRL: Self-regulated learning; LSU: Limited smartphone usage

\section{Acknowledgements}

Not applicable.

\section{Authors' contributions}

$\mathrm{KH}$ completed all initial design, implementation, analysis, and manuscript development. LB, DG and ES reviewed, revised, and approved study design, implementation, analysis and manuscript revisions. The authors read and approved the final manuscript.

\section{Funding}

No external funding was expended in support of this research.

\section{Availability of data and materials}

De-identified data and study materials are available by request from the corresponding author.

Ethics approval and consent to participate

The current study was approved by the university social-behavioral institutional review board and the Office of Research Integrity.

\section{Consent for publication}

Individual data use was approved by study participants in accordance with local and federal guidelines.

\section{Competing interests}

The authors declare that they have no competing interests.

\section{Author details}

'Department of Teaching and Learning, University of Nevada, Las Vegas, 4505 S. Maryland Parkway, Box \#453005, Las Vegas, NV 89154-3005, USA. ²Department of Educational Psychology and Higher Education, University of Nevada, Las Vegas, Las Vegas, NV, USA. ${ }^{3}$ Academic Success Center, University of Nevada, Las Vegas, Las Vegas, NV, USA.

Received: 2 June 2020 Accepted: 30 July 2020

Published online: 30 September 2020

\section{References}

Aharony, N., \& Zion, A. (2019). Effects of WhatsApp's use on working memory performance among youth. Journal of Educational Computing Research, 57(1), 226-245. https://doi.org/10.1177/0735633117749431.

Anshari, M., Almunawar, M. N., Shahrill, M., Wicaksono, D. K., \& Huda, M. (2017). Smartphones usage in the classrooms: learning aid or interference? Education and Information Technologies, 22(6), 3063-3079. https://doi.org/10.1007/s10639017-9572-7.

Ariel, Y., \& Elishar-Malka, V. (2019). Learning in the smartphone era: viewpoints and perceptions on both sides of the lectern. Education and Information Technologies, 24(4), 2329-2340. https://doi.org/10.1007/s10639-019-09871-w.

Bernacki, M. L., Vosicka, L., \& Utz, J. C. (2019). Can a brief, digital skill training intervention help undergraduates "learn to learn" and improve their STEM achievement? Journal of Educational Psychology. https://doi.org/10.1037/edu0000405.

Bråten, I., Lien, A., \& Nietfeld, J. (2017). Examining the effects of task instructions to induce implicit theories of intelligence on a rational thinking task: a cross-cultural study. Zeitschrift für Psychologie, 225(2), 146-156. https://doi.org/10.1027/21512604/a000291.

Brown, K. W. \& Ryan, R. M. (2003). The benefits of being present: mindfulness and its role in psychological well-being. Journal of Personality and Social Psychology, 84(4), 822-848. https://doi.org/10.1037/0022-3514.84.4.822. 
Chen, C.-W., \& Koufaris, M. (2020). Multi-device use: understanding the motivations behind switching between multiple devices during a task. International Journal of Human Computer Interaction, 0(0), 1-16. https://doi.org/10.1080/10447318. 2020.1726106.

Chen, Q., \& Yan, Z. (2016). Does multitasking with mobile phones affect learning? A review. Computers in Human Behavior, 54, 34-42. https://doi.org/10.1016/J.CHB.2015.07.047.

Dalvi-Esfahani, M., Wai Leong, L., Ibrahim, O., \& Nilashi, M. (2020). Explaining students' continuance intention to use mobile web 2.0 learning and their perceived learning: an integrated approach. Journal of Educational Computing Research, 57(8), 1956-2005. https://doi.org/10.1177/0735633118805211.

Deci, E. L., \& Ryan, R. M. (2012). Self-determination theory. In Handbook of theories of social psychology: volume 1, (vol. 1-1, pp. 416-437). Thousand Oaks: SAGE Publications Ltd. https://doi.org/10.4135/9781446249215.

Durak, H. Y. (2020). Cyberloafing in learning environments where online social networking sites are used as learning tools: antecedents and consequences. Journal of Educational Computing Research, 58(3), 539-569. https://doi.org/10.1177/ 0735633119867766.

Dweck, C. S. (2008). Mindset: the new psychology of success. New York: Random House Digital, Inc.

Ellis, B. J., Del Giudice, M., Dishion, T. J., Figueredo, A. J., Gray, P., Griskevicius, V., Hawley, P. H., Jacobs, W. J., James, J., Volk, A. A., \& Wilson, D. S. (2012). The evolutionary basis of risky adolescent behavior: Implications for science, policy, and practice. Developmental Psychology, 48(3), 598-623. https://doi.org/10.1037/a0026220.

Gorman, T. E., \& Green, C. S. (2016). Short-term mindfulness intervention reduces the negative attentional effects associated with heavy media multitasking. Scientific Reports, 6(1), 24542. https://doi.org/10.1038/srep24542.

Hartley, K., Bendixen, L. D., Olafson, L., Gianoutsos, D., \& Shreve, E. (2020). Development of the smartphone and learning inventory: Measuring self-regulated use. Education and Information Technologies. https://doi.org/10.1007/s10639-020-10179-3.

Hartley, K., Bendixen, L. D., Shreve, E., Gianoutsos, D., \& Olafson, L. (2020). Smartphone use and the self-regulated learner: relationships between type of use and metacognitive factors [paper session]. San Francisco: AERA Annual Meeting http:// tinyurl.com/u9acfph.

Hilpert, J. C., Stempien, J., Kraft, K. J. van der H., \& Husman, J. (2013). Evidence for the Latent Factor Structure of the MSLQ: A New Conceptualization of an Established Questionnaire. SAGE Open. https://doi.org/10.1177/2158244013510305.

Jeno, L. M., Adachi, P. J. C., Grytnes, J.-A., Vandvik, V., \& Deci, E. L. (2019). The effects of m-learning on motivation, achievement and well-being: a self-determination theory approach. British Journal of Educational Technology, 50(2), 669683. https://doi.org/10.1111/bjet.12657.

Kirschner, P. A., \& De Bruyckere, P. (2017). The myths of the digital native and the multitasker. Teaching and Teacher Education, 67, 135-142. https://doi.org/10.1016/J.TATE.2017.06.001.

Lepp, A., Barkley, J. E., \& Karpinski, A. C. (2015). The relationship between cell phone use and academic performance in a sample of U.S. college students. SAGE Open, 5(1), 2158244015573169. https://doi.org/10.1177/2158244015573169.

May, K. E., \& Elder, A. D. (2018). Efficient, helpful, or distracting? A literature review of media multitasking in relation to academic performance. International Journal of Educational Technology in Higher Education, 15(1), 13. https://doi.org/10. 1186/s41239-018-0096-z.

Morisano, D., Hirsh, J. B., Peterson, J. B., Pihl, R. O., \& Shore, B. M. (2010). Setting, elaborating, and reflecting on personal goals improves academic performance. The Journal of Applied Psychology, 95(2), 255-264. https://doi.org/10.1037/a0018478.

Mrazek, A. J., Ihm, E. D., Molden, D. C., Mrazek, M. D., Zedelius, C. M., \& Schooler, J. W. (2018). Expanding minds: growth mindsets of self-regulation and the influences on effort and perseverance. Journal of Experimental Social Psychology, 79, 164-180. https://doi.org/10.1016/J.JESP.2018.07.003.

Muis, K. R. (2007). The role of epistemic beliefs in self-regulated learning. Educational Psychologist, 42(3), 173-190. https://doi. org/10.1080/00461520701416306.

Muis, K. R., \& Duffy, M. C. (2013). Epistemic climate and epistemic change: Instruction designed to change students' beliefs and learning strategies and improve achievement. Journal of Educational Psychology, 105(1), 213-225. https://doi.org/10. 1037/a0029690.

Nguyen, N., Muilu, T., Dirin, A., \& Alamäki, A. (2018). An interactive and augmented learning concept for orientation week in higher education. International Journal of Educational Technology in Higher Education, 15(1), 35. https://doi.org/10.1186/s41239-018-0118-x.

Patterson, M. C. (2017). A naturalistic investigation of media multitasking while studying and the effects on exam performance. Teaching of Psychology, 44(1), 51-57. https://doi.org/10.1177/0098628316677913.

Pintrich, P. R., \& De Groot, E. V. (1990). Motivational and self-regulated learning components of classroom academic performance. Journal of Educational Psychology, 82(1), 33-40.

Pintrich, P. R., Smith, D., Garcia, T., \& Mckeachie, W. J. (1991). Motivated strategies for learning questionnaire manual, (pp. 1-79). https://doi.org/10.13140/RG.2.1.2547.6968.

Robbins, S. B., Lauver, K., Le, H., Davis, D., Langley, R., \& Carlstrom, A. (2004). Do psychosocial and study skill factors predict college outcomes? A meta-analysis. Psychological Bulletin, 130(2), 261-288. https://doi.org/10.1037/0033-2909.130.2.261.

Rosen, L. D., Carrier, L. M., \& Cheever, N. A. (2013). Facebook and texting made me do it: Media-induced task-switching while studying. Computers in Human Behavior, 29(3), 948-958. https://doi.org/10.1016/J.CHB.2012.12.001.

Schindler, L. A., Burkholder, G. J., Morad, O. A., \& Marsh, C. (2017). Computer-based technology and student engagement: a critical review of the literature. International Journal of Educational Technology in Higher Education, 14(1), 25. https://doi. org/10.1186/s41239-017-0063-0.

Schraw, G., \& Dennison, R. S. (1994). Assessing metacognitive awareness. Contemporary Educational Psychology, 19(4), 460-475.

Terry, C. A., Mishra, P., \& Roseth, C. J. (2016). Preference for multitasking, technological dependency, student metacognition, \& pervasive technology use: an experimental intervention. Computers in Human Behavior, 65, 241-251. https://doi.org/10. 1016/j.chb.2016.08.009.

Usher, E. L., \& Schunk, D. H. (2018). Social cognitive theoretical perspective of self-regulation. In D. H. Schunk, \& J. A. Greene (Eds.), Handbook of self-regulation of learning and performance, (2nd ed., pp. 35-51). Abingdon: Routledge. https://doi.org/ $10.4324 / 9781315697048$.

van Merriënboer, J. J. G., \& de Bruin, A. B. H. (2019). Cue-based facilitation of self-regulated learning: A discussion of multidisciplinary innovations and technologies. Computers in Human Behavior, 100, 384-391. https://doi.org/10.1016/j.chb. 2019.07.021. 
Walton, G. M. (2014). The new science of wise psychological interventions. Current Directions in Psychological Science, 23(1), 73-82. https://doi.org/10.1177/0963721413512856.

Yeager, D. S., Dahl, R. E., \& Dweck, C. S. (2018). Why interventions to influence adolescent behavior often fail but could succeed. Perspectives on Psychological Science, 13(1), 101-122. https://doi.org/10.1177/1745691617722620.

Yeager, D. S., Hanselman, P., Walton, G. M., Murray, J. S., Crosnoe, R., Muller, C., ... Dweck, C. S. (2019). A national experiment reveals where a growth mindset improves achievement. Nature, 573(7774), 364-369. https://doi.org/10.1038/s41586-0191466-y.

Zhang, W. (2015). Learning variables, in-class laptop multitasking and academic performance: a path analysis. Computers \& Education, 81, 82-88. https://doi.org/10.1016/j.compedu.2014.09.012.

Zimmerman, B. J., \& Kitsantas, A. (2014). Comparing students' self-discipline and self-regulation measures and their prediction of academic achievement. Contemporary Educational Psychology, 39(2), 145-155. https://doi.org/10.1016/J.CEDPSYCH. 2014.03.004.

Zimmerman, B. J., \& Schunk, D. H. (2011). Self-regulated learning and performance: an introduction and overview. In B. J. Zimmerman, \& D. H. Schunk (Eds.), Handbook of self-regulation of learning and performance, (pp. 1-13). Abingdon: Routledge.

\section{Publisher's Note}

Springer Nature remains neutral with regard to jurisdictional claims in published maps and institutional affiliations.

Submit your manuscript to a SpringerOpen ${ }^{\odot}$ journal and benefit from:

- Convenient online submission

Rigorous peer review

- Open access: articles freely available online

- High visibility within the field

- Retaining the copyright to your article

Submit your next manuscript at $\boldsymbol{\nabla}$ springeropen.com 